\title{
Nasal nicotine solution: a potential aid to giving up smoking?
}

\author{
M A H RUSSELL, M J JARVIS, C FEYERABEND, O FERNÖ
}

\begin{abstract}
A nasal solution was developed containing $2 \mathrm{mg}$ nicotine for use as a kind of liquid snuff. Its absorption was studied in three subjects. An average peak of plasma nicotine concentrations of $86.9 \mathrm{nmol} / 1(14.1 \mathrm{ng} / \mathrm{ml})$ was reached seven and a half minutes after taking the solution. This compared with an average peak of $158.4 \mathrm{nmol} / 1$ (25.7 $\mathrm{ng} / \mathrm{ml}$ ) one and a half minutes after completing (but seven and a half minutes after starting) a middle tar cigarette (1.4 mg nicotine) and an average peak of 52.4 nmol $/ 1$ (8.5 $\mathrm{ng} / \mathrm{ml})$ after chewing nicotine gum (2 $\mathrm{mg}$ nicotine) for 30 minutes.

The more rapid and efficient absorption of nicotine from the nasal nicotine solution than from nicotine chewing gum suggests that it might prove a useful aid to giving up smoking. Nasal nicotine solution might be particularly useful in smokers for whom the gum is less suitable on account of dentures or peptic ulcers or who experience nausea and dyspeptic symptoms from the gum.
\end{abstract}

\section{Introduction}

The use of nicotine chewing gum (Nicorette) as a temporary substitute for cigarettes has proved effective in reducing withdrawal symptoms and increasing success at giving up smoking. ${ }^{12}$ But nicotine is absorbed rather slowly from the gum and a substitute that delivered it more rapidly might be more effective as a treatment for smokers. Nicotine is absorbed very rapidly from dry snuff (powdered tobacco) taken into the nose. ${ }^{3}{ }^{4}$ Snuff is messy, however, and carries a slight risk of nasal cancer. There would be no such disadvantages with a nasal solution of nicotine. It would be free of all tobacco carcinogens and the numerous harmful gases and other products of combustion present in tobacco smoke. With this in mind we have developed a nasal nicotine solution for use as a kind of liquid snuff. This paper compares the absorption of nicotine from the nasal nicotine solution, nicotine chewing gum, and cigarette smoking in three subjects.

\section{Materials and methods}

The nasal nicotine solution consisted of $0.1 \mathrm{ml}$ of a $2 \%$ aqueous solution of nicotine $(2 \mathrm{mg})$ at $\mathrm{pH} 5.0$ without added buffer. To enable the solution to remain in the nose the viscosity was increased with a cellulose derivative. Each dose was made up in a small plastic container from which it was released by breaking off one end and squeezing. The nicotine chewing gum was the commercially available $2 \mathrm{mg}$

Addiction Research Unit, Institute of Psychiatry, London SE5 8AF M A H RUSSELL, FRCP, FRCPSYCH, senior lecturer

$M$ J JARVIS, BSC, MPHIL, clinical psychologist

Poisons Unit, New Cross Hospital, London SE14

C FEYERABEND, BSC, senior biochemist

AB Leo, Helsingborg, Sweden

O FERNÖ, former vice-president
Nicorette. The cigarette was a popular middle tar brand with standard machine smoked deliveries of $17 \mathrm{mg}$ tar and $1.4 \mathrm{mg}$ nicotine, but expected to deliver about $2 \mathrm{mg}$ nicotine when puffed in a manner more typical of human smokers.

The three subjects were healthy male members of our laboratory staff aged 30-50. One was a regular cigarette smoker who averaged about 20 a day. The other two were former cigarette smokers who smoked cigars occasionally. All tests were carried out after abstinence from smoking for at least 12 hours (confirmed by measuring expired air carbon monoxide values). The test cigarette was smoked as follows: the lighting up puff was not inhaled and subjects were then instructed to inhale one puff as deeply as possible every 40 seconds to a total of 10 puffs in six minutes. The butt of the test cigarette was analysed to determine the approximate intake of nicotine at mouth level for each subject $(2.7 \mathrm{mg}, 1.9 \mathrm{mg}$, and $1.3 \mathrm{mg}$; mean $1.97 \mathrm{mg}$ nicotine). The test piece of $2 \mathrm{mg}$ nicotine chewing gum was chewed for 30 minutes. Blood samples were taken from a forearm vein via a butterfly cannula and centrifuged within one hour. The plasma was then frozen until analysed for nicotine.

\section{Results}

The figure shows the average plasma nicotine concentrations of the three subjects. The peak values averaged $158.4 \mathrm{nmol} / \mathrm{l}(25.7 \mathrm{ng} / \mathrm{ml})$, $86.9 \mathrm{nmol} / \mathrm{l}(14.1 \mathrm{ng} / \mathrm{ml})$, and $52.4 \mathrm{nmol} / 1(8.5 \mathrm{ng} / \mathrm{ml})$ for the cigarette, nasal nicotine solution, and nicotine gum respectively. Although the peak nicotine concentration produced by the nasal nicotine solution averaged little more than half that from smoking, the rate of absorption was rapid with the average peak value occurring at seven and a half minutes in both cases. Measurement of the areas under the curves, with that produced by the cigarette taken as $100 \%$, showed the plasma nicotine concentrations from nasal nicotine solution and nicotine gum to be $75 \%$ and $43 \%$ respectively. A subjective nicotine "buzz" was experienced by all three subjects after taking the nasal preparation.
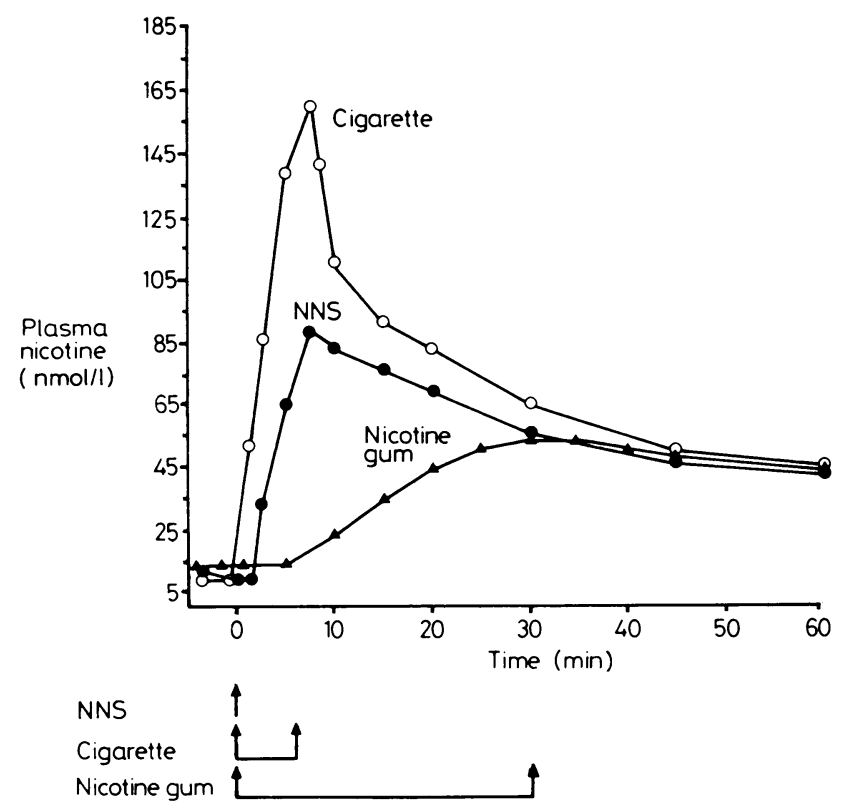

Average plasma nicotine concentrations of three subjects after smoking a cigarette, taking nasal nicotine solution (NNS), and chewing nicotine gum. Doses of nicotine were $2 \mathrm{mg}$ for nasal nicotine solution and nicotine gum and averaged $1.97 \mathrm{mg}$ (see text) for the cigarette.

Conversion: SI to traditional units-Nicotine: $1 \mathrm{nmol} / 1 \approx 0 \cdot 16 \mathrm{ng} / \mathrm{ml}$ 


\section{Comment}

Availability of nicotine from the nasal solution was clearly superior to that from the gum. The rate of absorption was more rapid and the areas under the concentration-time curves indicated that more nicotine was absorbed from the nasal solution than from the equivalent dose in the gum. Though improvements will be needed to make it more acceptable to smokers, these preliminary findings suggest that nasal nicotine solution might prove a useful aid to giving up smoking. It might be particularly useful in people with dentures or peptic ulcers and in those who experience nausea and dyspeptic problems with nicotine chewing gum.

Financial support for this work was provided by the Medical Research Council. The nasal nicotine solution was developed and supplied by AB Leo, Helsingborg, Sweden. We thank our colleagues
Professor M H Lader, Dr S R Sutton, and Mr R J West for helpful advice and Vera Amato for secretarial help.

\section{References}

${ }^{1}$ Raw M, Jarvis MJ, Russell MAH. Comparison of nicotine chewing-gum and psychological treatments for dependent smokers. $\mathrm{Br}$ Med $\mathcal{F} 1980$ $281: 481-2$.

${ }^{2}$ Jarvis MJ, Raw M, Russell MAH, Feyerabend C. Randomised controlled trial of nicotine chewing-gum. $\mathrm{Br}$ Med $\mathcal{f} 1982 ; 285: 537-40$.

${ }^{3}$ Russell MAH, Jarvis MJ, Feyerabend C. A new age for snuff? Lancet 1980 ;i : 474-5.

${ }^{4}$ Russell MAH, Jarvis MJ, Devitt G, Feyerabend C. Nicotine intake by snuff users. Br Med $\mathcal{F} 1981 ; 283: 814-7$.

${ }^{5}$ Feyerabend C, Russell MAH. Assay of nicotine in biological materials: sources of contamination and their elimination. 7 Pharm Pharmacol $1980 ; 32: 178-81$.

(Accepted 24 fanuary 1983)

\section{SHORT REPORTS}

\section{Is serum creatinine concentration a reliable index of renal function in rheumatic diseases?}

Uncontrolled observations in our hospital indicated that the serum creatinine concentration in patients with rheumatoid arthritis was lower than would be expected from direct clearance measurements of glomerular filtration rate. This suggested that the serum creatinine concentration, which is commonly taken as a useful index of kidney function, may not be reliable for that purpose in rheumatoid arthritis. We have therefore carried out a retrospective study in patients with normal and impaired kidney function.

\section{Patients, methods, and results}

All 54 patients from the department of rheumatology who were referred during two successive years for measurement of the glomerular filtration rate were studied. Thirty four of the patients had rheumatoid arthritis and the for the normal decrease in glomerular filtration rate with age we divided each patient's clearance value $\left(\mathrm{ml} / \mathrm{min} / 1.73 \mathrm{~m}^{2}\right)$ by the normal value for age ${ }^{3}$ (also in $\mathrm{ml} / \mathrm{min} / 1.73 \mathrm{~m}^{2}$ ) and multiplied the resulting quotient by 100 . This gave the clearance value and hence renal function of each patient expressed as a percentage of the expected normal for the patient (see table). Patients with a glomerular filtration rate exceeding $75 \%$ of normal were regarded as having normal kidney function, and those whose rate was below $75 \%$ of normal as having impaired kidney function.

The table gives the results. In both sexes and both kidney function groups the serum creatinine concentration was higher in the controls than in the patients with rheumatic disease. The difference was significant $(t$ test $)$ in those with normal kidney function. Five of the 26 rheumatic patients with impaired kidney function had a serum creatinine concentration below $80 \mu \mathrm{mol} / 1(0.9 \mathrm{mg} / 100 \mathrm{ml})$. None of the controls with impaired kidney function had such a low concentration. Two of the 28 rheumatic patients with normal kidney function had a serum creatinine concentration above $100 \mu \mathrm{mol} / 1(1.1 \mathrm{mg} / 100 \mathrm{ml})$. Of the 29 controls with normal kidney function, seven had serum creatinine concentrations above $100 \mu \mathrm{mol} / 1$.

Most of the rheumatic patients were receiving treatment with one or more drugs, and 37 were taking steroids. We could not find any association between the various single or combined drug treatments on the one hand and the relation between the glomerular filtration rate and serum creatinine concentration on the other.

Serum creatinine concentrations in patients with inflammatory joint diseases and controls. (Subjects grouped according to sex and renal function)

\begin{tabular}{|c|c|c|c|c|}
\hline & Renal function & $\begin{array}{c}\text { No of } \\
\text { patients }\end{array}$ & $\begin{array}{l}\text { Mean }{ }^{51} \mathrm{Cr} \text {-edetic } \\
\text { acid } \\
\text { clearance } \pm \mathrm{SEM} \\
\left(\mathrm{ml} / \mathrm{min} / 1.73 \mathrm{~m}^{2}\right)\end{array}$ & $\begin{array}{l}\text { Mean serum } \\
\text { creatinine } \pm \text { SEM } \\
(\mu \mathrm{mol} / \mathrm{l})\end{array}$ \\
\hline \multicolumn{5}{|c|}{ Men } \\
\hline $\begin{array}{l}\text { Patients with inflammatory joint disease } \\
\text { Controls } \\
\text { Patients with inflammatory joint disease } \\
\text { Controls }\end{array}$ & $\begin{array}{l}\geqslant 75 \% \text { of normal } \\
\geqslant 75 \% \text { of normal } \\
<75 \% \text { of normal } \\
<75 \% \text { of normal }\end{array}$ & $\begin{array}{r}15 \\
15 \\
9 \\
9\end{array}$ & $\begin{array}{l}99 \div 4 \cdot 7 \\
95 \div 4 \cdot 1 \\
56 \div 6 \cdot 2 \\
57 \pm 6 \cdot 3\end{array}$ & $\begin{array}{r}75+3.9 \\
94=0.4 \\
119=14 \cdot 3 \\
143 \pm 17 \cdot 4\end{array}$ \\
\hline \multicolumn{5}{|c|}{ Women } \\
\hline $\begin{array}{l}\text { Patients with inflammatory joint disease } \\
\text { Controls } \\
\text { Patients with inflammatory joint disease } \\
\text { Controls }\end{array}$ & $\begin{array}{l}\geqslant 75^{\circ} \text {, of normal } \\
\geqslant 75^{\circ} \text { ", of normal } \\
75^{\circ} \text { ", of normal } \\
75^{\circ} \text {, of normal }\end{array}$ & $\begin{array}{l}13 \\
14 \\
17 \\
16\end{array}$ & $\begin{array}{l}93 \pm 4 \cdot 6 \\
89+3 \cdot 9 \\
44 \pm 3 \cdot 4 \\
44 \pm 4 \cdot 4\end{array}$ & $\left.\begin{array}{r}64: 2 \cdot 1 \\
80 \\
115+14 \cdot 4 \\
159 \pm 22 \cdot 8\end{array}\right\}=0 \cdot 001$ \\
\hline
\end{tabular}

Conversion: SI to traditional units-Creatinine: $1 \mu \mathrm{mol} / 1 \simeq 0.01 \mathrm{mg} / 100 \mathrm{ml}$

remaining 20 spondyloarthritides or various types of systemic inflammatory diseases. For each study patient the next patient in the laboratory record book of filtration rate measurements without inflammatory rheumatic disease, of the same sex and age $(+20 \%)$, and with a similar $(+20 \%)$ glomerular filtration rate served as a control. All 108 patients had known or suspected renal disease.

Glomerular filtration rate was measured as the plasma clearance of ${ }^{51} \mathrm{Cr}$-edetic acid. 1 Serum creatinine concentration was measured simultaneously. ${ }^{2}$ Clearance measurements, in $\mathrm{ml}$ plasma/min, were related to body size by dividing by the body surface area and multiplying by 1.73 . (In renal physiology the ideal body surface area is traditionally quoted as $1.73 \mathrm{~m}^{2}$.) The resulting clearance values were expressed in $\mathrm{ml} / \mathrm{min} / 1.73 \mathrm{~m}^{2}$. To allow

\section{Comment}

Creatinine is formed in the skeletal muscles and excreted by the kidneys, mainly by glomerular filtration. For a given rate of glomerular filtration the serum creatinine concentration will vary with muscle mass. Hence a reasonable explanation for our findings is that the patients with rheumatic disease had a smaller muscle mass than the controls. Indeed, many of the rheumatic patients had severe or moderate muscular atrophy, though we were not able to quantify this The situation is probably similar to that in atrophy as a result of poliomyelitis. $^{4}$ 